\title{
THE CAPITALIST WORLD-SYSTEM AND US COLD WAR POLICIES IN THE CORE AND THE PERIPHERY: A COMPARATIVE ANALYSIS OF POST-WORLD WAR II AMERICAN NATION-BUILDING IN GERMANY AND KOREA
}

\author{
Y. Hugh Jo \\ Department of Political Science \\ Westfield State University \\ HJo@westfield.ma.edu
}

\begin{abstract}
In response to the emerging cold war, why did the United States stress industrial expansion in Western Europe but focus on primary production alongside policing operations in the nonwestern world? Examining US postwar occupation in Germany and Korea from a world-systems perspective, this article argues that a given country's standing in the capitalist economy generally shapes American foreign policy toward that particular country in the early cold war years. A paladin of system-wide prosperity and peace, the United States sought to restore the international division of labor after World War II. Reactions varied across the system, however, because of distinct socio-economic developments. The presence of capital-intensive exportdependent industry afforded western Germany flexible labor-management relations. Politics was overall stable there, and America dispensed with heavy-handed intervention. In southern Korea, labor-exploitive tenancy farming rendered interclass compromise virtually impossible. As intransigent peasants threatened the market economy, the United States used force to keep the ally in the system.
\end{abstract}

\section{INTRODUCTION}

It has been pointed out that US response to the emerging cold war in Europe differed from its policy toward Africa, Asia, and Latin America (Hogan 1987; Block 1977; Kolko and Kolko 1972). In coping with challenges from nationalists/leftists, the United States facilitated industrial production, economic growth, and balanced distribution of wealth in postwar Europe. Politics of output maximization and welfarism helped American allies attenuate interclass tensions and contain the development of unmanageable political troubles (Lundestad 1984; Maier 1977). Such emphasis on collaboration and industrialization was often absent outside Western Europe in the early cold war years. The United States underscored the production of raw materials and foodstuffs in the less-developed world (Plake 1951: 36). To defuse threats from "hostile elements," it carried out heavy-handed intervention in many Third World countries (Kahin and Kahin 1995; Gibbs 1990). The puzzle is why early US cold war policy in industrialized nations diverged from its approach in less-developed countries; why the former occasionally revolved around industrial expansion while the latter around primary production and policing operations.

American cold war policy has been an important topic of discussion in international relations and history. Many works (Kahin and Kahin 1995; Gibbs 1990; Hogan 1987) on this 
subject, however, analyze one single country/region and miss the fundamental unity in American efforts to tackle postwar challenges comprehensively across the system. ${ }^{1}$ Leffler (1992) and McCormick (1989) scrutinize US global strategies and find them varying in different regions; still, neither looks into interclass relations within countries worldwide for an answer to the hegemon's disparate foreign policy behavior. This omission is common as well among scholars, who approach hegemony from a Gramscian perspective. To explain why hegemony is more consensual in the core but laden with conflict in the periphery, they (Cox 1996; Augelli and Murphy 1993) mostly focus on the presence/absence of economic development, social institutions, and ideologies consistent with the dominant order. Missing in the scholarship is research on how patterns of socio-economic developments diverge within the system and how such variations shape the hegemon's foreign policy outcomes.

This article seeks to shed light on a hegemonic state's disparate foreign policy behavior in different regions by drawing upon world-systems theory. This paradigm pays close attention to how pressures generated by the operations of free market forces limit economic activity and political developments in the system (Wallerstein 1979: 222-223). Yet, this study expands upon world-systems theory by taking into account interclass relations in industrialized nations vis-à-vis less-developed countries; it analyzes institutionalized patterns of labor-management and peasantlandlord relationships in the core and the periphery of the capitalist world-system. In addition, this paper brings in realist and neo-pluralist insights and assesses their contribution to the understanding of US cold war policy. Just like other paradigms, these theories have different focuses and elaborate on certain events better than others. This article demonstrates that worldsystems theory, realism, and neo-pluralism complement each other and together provide a more complete explanation of postwar US foreign policy in various regions.

To answer why US cold war policy has different implications around the world, this article looks into American military occupation in western Germany and southern Korea. ${ }^{2} \mathrm{~A}$ comparative analysis of the hegemon's nation-building in countries at different stages of economic development helps appreciate systemic pressures exerted on postwar US foreign policy. In dealing with security threats, the American hegemon considered the allies' factor endowments of the interwar years and assigned them different functional roles for expeditious postwar recovery (Kindleberger 1987). This case selection also offers a rare opportunity to observe US postwar policy in an undiluted form. Its victorious, indomitable superpower status permitted America to carry out many momentous programs with minimal interference from indigenous forces. This case selection furthermore allows an appraisal of realism, neo-pluralism, and worldsystems theory. Germany and Korea were bulwarks of the United States' anti-Soviet containment policy. Both allies also entailed intense policy debates among different groups in America.

\footnotetext{
${ }^{1}$ For example, National Security Council memorandum (NSC) 61 (Truman Papers, President's Secretary's Files (PSF), Box 172) noted in May 16, 1950 that: "U.S. assistance programs in the Far East are but one phase of the world-wide problem of providing economic stability and raising living standards and efforts to coordinate such programs must be consistent with actions on the larger problems. Accordingly, a global approach rather than a narrow regional approach is required, and actions in connection with this effort should be taken with due regard to their effect upon areas outside the Far East."

${ }^{2}$ Western Germany refers to the areas the United States, Britain, and France each occupied after World War II. These three occupation zones eventually merged and formed the Federal Republic of Germany (West Germany). Southern Korea refers to the area, south of the $38^{\text {th }}$ parallel, under the American occupation. The Republic of Korea (South Korea) was established there in 1948.
} 


\section{COLD WAR POLICIES IN THE CORE AND THE PERIPHERY 430}

Nonetheless, Germany was situated in the core and Korea in the periphery of the capitalist worldsystem.

This study argues that a given country's standing in the capitalist world-system generally shapes American foreign policy toward that particular country in the early cold war years. In an attempt to circumvent a looming depression and arrest Soviet expansionism after World War II, the US hegemon proceeded to restore the worldwide division of labor. Because of uneven economic development and political challenges within the system, American cold war policy gave rise to disparate outcomes in different regions. This article starts with a brief analysis of world-systems theory and interclass relations in the core and the periphery. Scrutinizing archival materials of the Truman presidency, ${ }^{3}$ this paper then traces the formulation and implementation of early US cold war policy: America's quest for a new world order, socio-economic conditions in Germany and Korea, and the consequences of US occupation policies in the two countries. This article concludes by evaluating some merits of world-systems theory, alongside realism and neo-pluralism, in studying postwar American foreign policy.

\section{EXPLAINING DISPARATE OUTCOMES OF US COLD WAR POLICY}

For realists (Walt 1987; Waltz 1979), foreign policy behavior is explained by the state's incessant drive for power and survival. In pursuance of these fundamentals, the state makes cost-benefit calculation and picks policies that serve its security needs to the highest degree. It often forms partnership with other states and balances against power/threats. Neo-pluralists (Fordham 1998) argue that foreign policy behavior is a function of competition for influence among diverse factional interests. Business corporations normally have the upper hand in shaping policy outcomes, thanks to their intimate ties with top policymakers, greater control of campaign funds, and the relative ease in organizing themselves. While realism and neo-pluralism delve into international constraints and indigenous power struggles respectively, they stop short of asking how interclass relationships take shape under systemic pressure and how these variables limit American foreign policy choices in different regions. World-systems theory has good potential to fill the gap, since it analyzes how inherent forces of a free market determine economic structures and internal power relations in various parts of the world.

The gist of world-systems theory is that the dynamics of a free market economy - e.g., the drive for profit maximization - condition the specialization of productive activity, evolution of interclass relations, and rise of state institutions. ${ }^{4}$ Capitalist development entails a single

\footnotetext{
${ }^{3}$ This article relies on presidential papers and State Department advisors' personal papers. State Department officials' opinions, Policy Planning Staff documents, and National Security Council memos deserve special attention. Not only was the State Department in charge of postwar planning under the Roosevelt Administration (Domhoff 1990), but this department also wielded greater influence than Defense, Treasury, or the Joint Chiefs of Staff during the Truman years in shaping America's postwar design (Harry S. Truman Library Oral History Interview with Paul H. Nitze: 218-219).

${ }^{4}$ Wallerstein (1979: 48) argues that “... the economic development of particular states in modern times ... has been a function of their role in a world-economy, and ... the political developments within such states have reflected the pressures that derive from the consequences for various groups of the condition of this world-economy at a given time."
} 
division of labor between the core, semi-periphery, and periphery. Marked by profitable business undertakings, the core after World War II exported sophisticated industrial products and controlled the flow of investment capital. The periphery supplied mostly raw materials and mineral resources to the world market. The semi-periphery combined semi-skilled labor with imported technology and manufactured commodities for export (Shannon 1989). Hegemony appears when a core state achieves overall supremacy in production, commerce, and finance, and imposes its "rules and wishes" in economic, political, and other realms (Wallerstein 1984: 38-39). The hegemonic state becomes a paladin of worldwide peace and prosperity. It fights for economic expansion to promote prosperity; checks the rise of military rivals to preserve systemic stability; and builds supranational institutions to consolidate its hegemonic position (Wallerstein 1979).

In creating favorable conditions for overall prosperity and peace after World War II, the hegemonic power would encounter little systemic threats in the core. Here, industrial production relied increasingly on mechanization, and much less on raw human labor. Thus, wages as a percent of value-added were relatively low, and businesses could meet workers halfway over basic issues (Ferguson 1984). Wage concessions moderated labor militancy, and unions often confined their calls to economic demands. With spreading landownership, class antagonisms subsided in the countryside as well (Paige 1975). The state acted more like a mediator in the core; workers/farmers were co-opted into the democratic process and made their cases through formal political channels. On the other hand, the hegemonic power after World War II would face serious challenges in the periphery. Here surplus extractive demands were usually met through extensive utilization of cheap labor. Heavy reliance on human labor disposed businesses/landlords rather hostile to economic concessions and worker/peasant empowerment (Cumings 1981). Impoverished and disenfranchised peasants/workers were more susceptible to subversive groups' promise of fundamental remedies. They also grew resentful at the state that acted more or less as a guarantor of ruling class privileges (Paige 1975; Migdal 1974).

\section{AMERICA'S QUEST FOR A NEW WORLD ORDER}

The United States since the early 1940s sought to uphold a "free and democratic way of life" in America by protecting certain geographical areas - the "Grand Area" - against hostile forces and fostering prosperity there. ${ }^{5}$ This quest was seriously hampered by widespread wartime destruction of Europe and severe dislocation of international trade. At the root of the problems was that Europe could not earn the means to pay for its imports from the American market, and this raised the alarm about a postwar depression similar to the one after the Great War (Gaddis [1972] 2000: 21-22). The existence of the Soviet Union further complicated matters, coercing the United States to rely more on "reform" than "repression" in constructing a new world order (Silver and Slater 1999). Despite substantial damage it sustained in the war, the USSR could still cajole neighbors

\footnotetext{
${ }^{5}$ Domhoff (1990) and Shoup and Minter (1977) argue that the Grand Area, the regions the United States considered crucial for proper functioning of the American economy, included the Western Hemisphere, the Pacific area, and the British Empire, to which Germany and Western Europe were later added.
} 


\section{COLD WAR POLICIES IN THE CORE AND THE PERIPHERY 432}

into making concessions and thereby preempt America's recovery plan. ${ }^{6}$ Of equal importance, this unrelenting adversary could pose a direct military threat to US hegemony. If Moscow successfully combined its military potential with European/ Japanese industrial might, it could tilt the balance of power against America (Leffler 1992).

In the face of mounting challenges to peace and prosperity, the United States moved to facilitate worldwide economic integration. ${ }^{7}$ America considered the "requirements of an international division of labor" and assigned its allies different functional roles. ${ }^{8}$ Technology-, human resource-rich European countries were encouraged to resuscitate industrial production. Since basic human capital for industrialization already existed there, Western Europe could resume growth easily with the infusion of capital and raw materials. By virtue of their highlyskilled work force and well-staffed government services, these countries in the core could put scarce resources to good use. In addition to helping the allies rebuild their industry, the United States pushed for trade liberalization on the European continent. It helped lower protectionist barriers, stabilize local currencies, and introduce a multilateral clearing mechanism. Since Western Europe possessed valuable economic resources and formidable military potential, this region counted more in America's cold war strategy.

In the periphery, the United States sought to expand raw materials production by promoting political stability and American investments. Virtues of industrialization were widely trumpeted, but emphasis there remained on production of grains and minerals so as to enable postwar recuperation in Europe/Japan. ${ }^{9}$ American businesses should now be invited in for primary production, as European assets in the periphery had been mostly liquidated to finance the previous war (Truman Papers, PSF, Box 216). US direct investments would also facilitate lessdeveloped areas' purchase from Europe/Japan and ameliorate dollar shortages in the core. ${ }^{10}$ This blueprint was doomed, however, as long as the periphery was mired in political turmoil. To lure its wary corporations, America devised legal, institutional mechanisms for the protection of

\footnotetext{
${ }^{6}$ McCormick (1989: 59-64) asserts that the Kremlin had ties with some political parties and unions in Western Europe, and exerted ideological authority over independence/leftist movements in less-developed areas.

${ }^{7}$ Kindleberger (Harry S. Truman Library Oral History Interview with Charles P. Kindleberger: 12) observed that world economic integration had been in American policymakers' mind ever since the early days of World War II, and US assistance to the allies and wartime agreements - e.g., Lend-Lease, the Atlantic Charter, and the Hot Springs meeting - were pursued accordingly.

${ }^{8}$ Machlup (1977: 18) explains that integration of the world economy means "tailoring the economic fabric of each country to the requirements of an international division of labor." It denotes promoting functional specialization of industrial and primary producing countries, in accordance with the structural needs of international trade. Paul Hoffman of the Economic Cooperation Administration (Truman Papers, PSF, Box 124) urged in April 1948 that "Each participating nation, looking at the operations of its own national life, must face up to readjustments to satisfy the requirements of a new world. These readjustments cannot be made in the course of national action along the old separatist lines."

${ }^{9}$ National Security Council memorandum (NSC) 51 (Truman Papers, PSF, Box 172) stated that "Political independence will give impetus to the ambitions of the SEA [Southeast Asian] countries to diversify their economies, including modest industrialization... However, the attainment of U.S. objectives with respect to Japanese, Indian and Western European self-support will require continued emphasis at least over the near term, on production of foodstuffs and raw materials in this area."

${ }^{10}$ The Point IV Program was in actuality devised to tackle Europe's dollar gap problems that appeared to persist after the termination of the Marshall Plan (Walter Salant Papers, Point IV File, Box 2).
} 
invested properties. The United States also stepped up its containment efforts, endorsing independence struggles by pro-Western moderates and crushing subversive movements by radical leftists. ${ }^{11}$

America's postwar policy of reconstituting an international division of labor resulted in different outcomes, owing to divergent socio-economic developments. Early industrialization ushered in an era of trade unionism and spreading farm-ownership in the core. As brisk economic growth and labor-management compromise buttressed political stability, the US hegemon seldom resorted to heavy-handed interventionism in Western Europe (Hogan 1987). Survival of a free market was precarious in the periphery, however. Raw materials producing economies often bred poverty and social unrest in Africa, Asia, and Latin America. To preserve a capitalist economy there, the United States clamped down on revolutionary movements and shored up the military establishment. Washington indeed held out little hope of democratic development in the periphery. ${ }^{12}$ Such skepticism, combined with ignorance of local culture and certain bias, also contributed to America's frequent meddling in the less-developed world. ${ }^{13}$

\section{POSTWAR US POLICIES IN OCCUPIED GERMANY AND KOREA}

\section{Development of Postwar American Foreign Policy Toward Germany and Korea}

Postwar American foreign policy was shaped in large part by the Council on Foreign Relations and its associates in the State Department (Domhoff 1990; Shoup and Minter 1977). Exploring the question of durable peace upon the outbreak of World War II, the Council organized the War and Peace Studies project and discussed ways to safeguard American interests in postwar

\footnotetext{
${ }^{11}$ American military intervention in troubled spots was not just a mechanical response to appeals from affected corporations, nor grandiose pursuit of ideological goals/security interests. Establishing order in less-developed areas was critical, so that American businesses could be induced to invest there. White House Council of Economic Advisors (Keyserling Papers, Council of Economic Advisors File, Box 9) asserted that "United States private capital, with ample opportunities for domestic investment at attractive rates of return, has shown no great tendency to travel... It must be recognized that private capital cannot be dragooned. But it can be challenged and stimulated. Continued success of our overall foreign policy, with the resultant increase in stability in foreign areas, will serve as such a stimulus." The Congress, in the same vein, sought to supply "collective goods" necessary to reduce risks involved in foreign investments. Plake (1951: 18) notes that the US House of Representatives passed in 1950 "An Act to Provide Foreign Economic Assistance" to ensure American corporations "that they will not be deprived of their property without prompt, adequate, and effective compensation; that they will be given reasonable opportunity to remit their earnings and withdraw their capital; ... that they will enjoy security in the protection of their persons and property, including industrial and intellectual property, and nondiscriminatory treatment in taxation and in the conduct of their business affairs."

${ }^{12}$ State Department officials (Policy Planning Staff 1983: 122) confided that "[we] should cease to talk about vague and - for the Far East - unreal objectives such as human rights, the raising of the living standards, and democratization."

${ }^{13}$ Moon (1997) points out racism and sexism in American society as a primary cause of differences in US foreign policy toward its allies. American troops in West Germany and South Korea were regulated by different and unequal sets of the Status of Forces Agreement (SOFA). Sexist stereotypes of Asian women in America contributed to widespread prostitution around military bases in many Asian countries.
} 


\section{COLD WAR POLICIES IN THE CORE AND THE PERIPHERY 434}

settlement. As the nation entered into full belligerency, this coterie of top corporate executives and internationalist intellectuals influenced America's postwar planning through institutionalized channels (Domhoff 1990). When the Advisory Committee on Postwar Foreign Policy was created in the under-staffed State Department, the Council provided a recruitment pool for the agency. The Advisory Committee acted as a vehicle for incorporating War and Peace Studies project proposals into the government's postwar design (Shoup and Minter 1977). The Council called for rehabilitation of Germany and Japan, shorn of military might and authoritarian controls, and their early integration into the new world order (Eisenberg 1996).

When the war ended in Europe, however, the Council's position on German rehabilitation was overshadowed by charged responses to the revelation of Nazi atrocities and wanton destruction. With anti-business "New Dealers" still placed in the Treasury and other key posts, the US government initially backed punitive reform in liberated Germany - e.g., the Morgenthau Plan, Joint Chiefs of Staff directive (JCS) 1067, and Potsdam Agreement (Gimbel 1968). Germany's economic structures would be completely overhauled. Most of the mineral resources produced in the country would be exported to other part of Europe; manufacturing of key industrial goods would be closely supervised. The United States also sought to purge Germany of fascist elements that had overthrown the fragile democracy. Political power was to be decentralized, with local and provincial governments wielding substantial power. Workers were nudged into forming trade unions, so as to check industrial monopoly (Eisenberg 1996). These draconian measures were soon questioned, however, in the midst of new developments.

In maintaining a viable electoral coalition, American political leaders often listened to leading business interests. President Truman generally advocated foreign policy initiatives preferred by multinational corporations in an effort not to alienate this core constituency. ${ }^{14} \mathrm{He}$ authorized the State Department with pro-business orientation to formulate US military occupation policies in the former Axis countries. ${ }^{15}$ This department interpreted wartime agreements on Germany rather loosely, watering down drastic provisions and rallying support for its reconstruction (Gaddis [1972] 2000; Eisenberg 1996). The State Department also set the tone for American postwar policy in Korea. Although the Military Governor reported directly to the War Department, he relied on State Department political, economic advisors and his decisions mostly reflected the view of the foreign policy establishment. Initial bureaucratic wrangling left US official policy in Korea undecided for the time being, but State Department containment advocates began to take the center-stage by 1947 (Cumings 1981).

As the cold war intensified and European recovery seemed ever more elusive, the United States gravitated toward the Council's idea of rebuilding Germany. This country had been for

\footnotetext{
${ }^{14}$ Fordham (1998) argues that a primary motive behind President Truman's acceptance of NSC 68 recommendations in 1949 - 50 was maintaining the Democratic coalition, led by capital-intensive multinational corporations. Business interests were firmly supportive of NSC 68, and Truman could not afford to estrange the corporate community by not endorsing increases in defense spending and foreign aid.

${ }^{15}$ President Truman (Student Research File, Box 1) issued a directive in May 1946 that put the State Department in charge of policy formulation and the War Department in charge of policy implementation. The Directive clarified that "(1) The State Department will be responsible for formulation of governmental policy with regard to U.S. participation in the occupation and government of the Occupied Areas in question [Germany, Austria, Japan and Korea]; (2) The War Department will be responsible for execution and administration of policy with respect to U.S. participation in the occupation and government of these Occupied Areas."
} 
many decades the workshop of Europe, processing raw materials into industrial products for neighboring countries. Manufactured goods had accounted for 65 to 80 percent of German exports throughout the interwar period (Lewis 1941). Germany's top export items included machine tools, iron and steel products, coal, chemicals, motored vehicles, and electrical machinery (see Figure I below). These capital-intensive, heavy industrial goods had been the lifeblood of European economic expansion (Truman Papers, PSF, Box 218). Although Germany's once prominent industry and infrastructure were gone by the war's end, this country still commanded advanced technologies, managerial prowess, and human capital. Without utilizing these resources, European recovery would be a lot more costly and require extensive government intervention in economy.

Figure 1. Germany's International Trade (Annual Average in \%, 1934-37) ${ }^{16}$

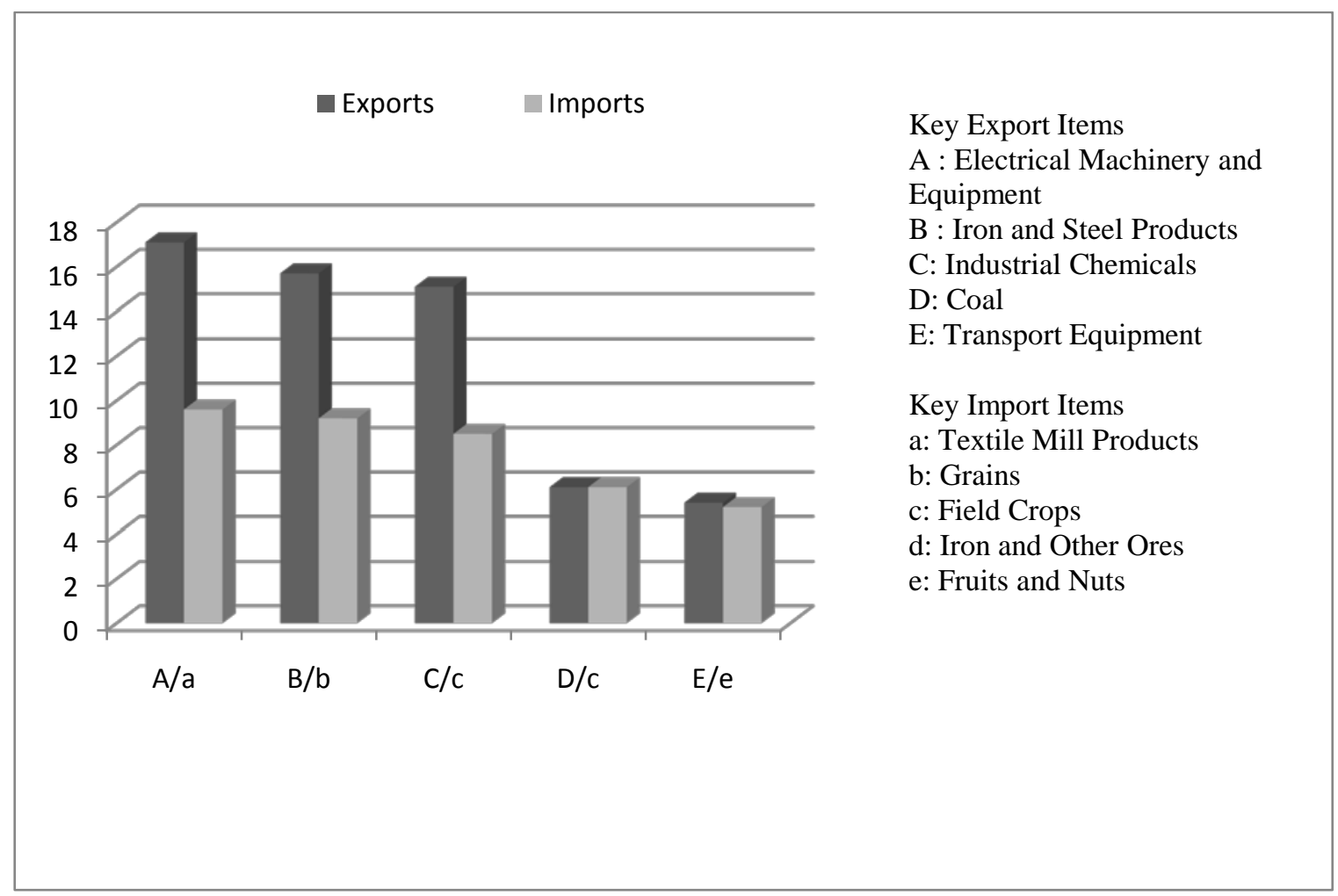

The United States envisioned that South Korea should be periphery/semi-periphery in the East Asian economy and contribute to Japanese reconstruction. ${ }^{17}$ Korea had long been an important source of grain supply to Japan. The colony supplied the Japanese with $15 \%$ of their

\footnotetext{
${ }^{16}$ US Department of Commerce 1968: 65-74.

17 The US Central Intelligence Agency (Truman Papers, PSF, Box 219) reported that "As in the past, Japan, for normal economic functioning on an industrial basis must have access to the Northeast Asiatic areas notably North China, Manchuria, and Korea - now under direct, indirect, or potential control of the USSR."
} 
rice consumption and $14 \%$ of soybeans. It was also the world's sixth largest seafood producer and made up Japan's entire shortage in fish and marine products (Meade 1951: 25-26). When the specter of unprecedented starvation haunted postwar Japan, ${ }^{18}$ imports of rice and other grains from the former colony would alleviate its food shortages and allow the dollar-deprived nation to save precious hard currencies (Borden 1985). In addition, Korea would offer a desperatelyneeded market for Japanese products. Colonial Korea purchased heavily from Japan textile goods, industrial chemicals, and machinery (see Figure II below). Reinstating the old trade link would help rebuild Japan's war-ravaged economy. ${ }^{19}$

Figure 2. Korea's International Trade (Annual Average in \%, 1934-37) ${ }^{20}$

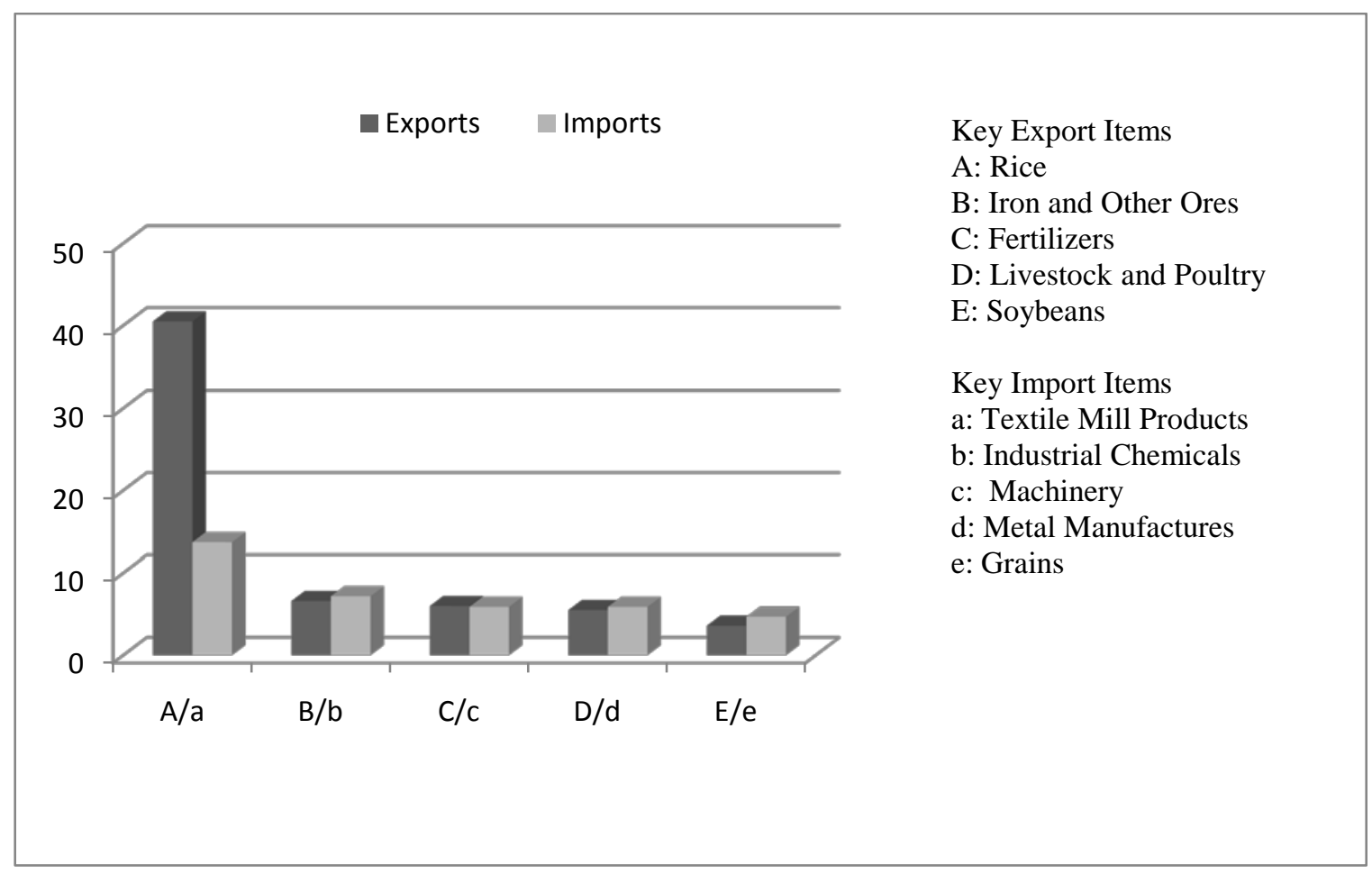

Korea's strategic value weighed more heavily than its remote economic potential, as America moved to remake Japan the anchor of anti-Soviet policy in Asia. Ever since communist victory in China grew irreversible, the United States began to groom Japan as its economic, military partner. Before Moscow could get a foothold in this island nation, the United States

\footnotetext{
${ }^{18}$ State Department officials (Department of State 1948: 954-958) frankly acknowledged that "Japanese food production is being pressed as hard as possible. All available area is being cultivated; including former golf courses and air fields... Japan's major economic needs today are sufficient rice, textiles, housing and coal."

${ }^{19}$ Meade (1951: 26) opines that "... both nature and circumstances have so linked the two economies of [Japan and Korea] that their close coordination would appear to be a demographical necessity."

${ }^{20}$ US Department of Commerce 1968: 336.
} 
needed to block a communist upsurge by rebuilding Japan's economy. This scheme, however, aroused acrimonious responses and undisguised threats from victims of earlier Japanese aggression. ${ }^{21}$ If entire Korea fell under communist rule and posed direct military menaces, Japan would become more reluctant to go along with the American plan and provoke bitter neighbors (Kofski n.d.). At least part of Korea should thus remain "independent." ${ }^{22}$ By defending Korea - a country of little military value on the frontline, the United States sought to entice Japan to join exclusively the free market bloc and deny the Soviets various prizes this only industrialized nation in the Far East could offer.

\section{Conditions for Democratic Development in Germany and Korea}

To contribute to the United States' postwar goals, Germany and Korea needed to become democratic allies. Germany was a core country in the capitalist world-economy, and capitalintensive export-dependent industries endowed this country with a structural foundation for postwar democratic development. ${ }^{23}$ Salaries constituted a small fraction of value-added for the chemical, electrical, and machine tool industries. Investing heavily in mechanization, these industrial leaders obtained profits through productivity improvement. They could hence develop overall tolerance towards higher wages and social welfare programs. German labor, for its part, relinquished "political strikes," restricting its demands to "bread-and-butter" issues (Abraham 1981). Improving rural conditions kept class differences muted in the countryside. As landownership penetrated into the remote corner of the west and south, affluent farmers embraced the sanctity of private property and disavowed revolutionary ideologies by the early $20^{\text {th }}$ century (Moeller 1986).

Korea was a peripheral country in the capitalist world-economy, and rural impoverishment under Japanese occupation made it next to impossible for liberal democracy to survive in the post-colonial period. Under the feudalistic land tenure system, Korea's landlords satisfied their surplus appropriation needs by squeezing more out of peasants. Subject to onerous lease terms, Korean peasants were easily swept into the vicious circle of food shortage, heavy

\footnotetext{
${ }^{21}$ The communist China and the Soviet Union were engaged in propaganda efforts to thwart Japanese rearmament. A January 28, 1951 article in The People's Daily (Truman Papers, PSF, Box 219) commented that: "The Chinese people certainly cannot tolerate the rearming of that country [Japan] by the Americans... If America arbitrarily carries out its plot to rearm Japan, the powerful peoples of China, the Soviet Union, and other Asian countries certainly cannot ignore it and a tense situation would ensue in the East. In such a case, the Japanese people would be the first victim."

${ }^{22}$ A Report to the President (Student Research File, Box 1) observed that "A Soviet-dominated Korea would constitute a serious political and psychological threat to ... the Ryukyus and Japan, and hence to United States strategic interests in the Far East. It is therefore in the best interest of the United States to ensure the permanent military neutralization of Korea. Neutralization can only be assured by its occupation until its future independence as a buffer state is assured."

${ }^{23}$ According to Abraham (1981), Germany's capital-intensive export-dependent industries, including the chemical, electrical, and machine tool manufacturers, forged the "Grand Coalition" with the organized labor in the 1920s that brought about democracy in the Weimar Republic. The presence of capital-intensive export-dependent industries did not always lead to democracy; but, this industrial sector spearheaded the alliance between labor and capital, and afforded many developed countries the cornerstone of social democracy in the $20^{\text {th }}$ century.
} 
borrowing, and default (Cumings 1981). Dismal conditions in rural areas jolted indigent peasants out of farming and forced them in droves to nearby cities, but situations were no better there. Extremely low wages and despicable working conditions were the hallmark of Korea's infant industries. Factory owners brooked no unions, let alone social welfare programs. Such an oppressive system was buttressed by the colonial state that maintained "security" laws and slapped harsh sentences on violators (Eckert 1991).

Once the totalitarian Japanese rule was overthrown, peasants and workers emerged as a driving force for thorough reform in liberated Korea. Japanese occupation stirred up the traditional village. It deepened rural poverty and triggered massive out-migration of dispossessed peasants. Those who fled the countryside degenerated into day-laborers in cities or overseas. These workers were buffeted there by the whims of an unrestrained market. Furthermore, they were exposed to foreign ideas that offered a remedy for their abject poverty, unmitigated exploitation, and political disenfranchisement. These re-born workers returned home poor and aggrieved after liberation by the hundreds of thousands, seeking to reclaim their previous status. ${ }^{24}$ Not unexpectedly, they played a crucial role in spreading progressive ideologies and radical movements (Cumings 1981).

\section{Economic Recovery and Emergence of Liberal Democracy in Germany}

In raising Germany as the engine of European recovery, the United States implemented carefully coordinated policies. With various leverages attached to overseeing rehabilitation programs, Washington virtually rewrote Germany's economic policy. ${ }^{25}$ Greatest attention was given to restoring the production of fuel, capital goods, and industrial commodities (Mayer 1969). Economic stabilization measures were pursued simultaneously. Balancing the budgets took precedence over full employment, for fear the economy might overheat and siphon off goods from export. Tight monetary policy was adopted to control inflation and make German products more affordable in the world market. The New Deutsche Mark was introduced, dramatically improving overall productivity and industrial output (Eisenberg 1996).

Since independent political structure was deemed indispensable for faster recovery, the United States proceeded to create a West German state. As Military Governor General Clay (Gimbel 1968: 197) noted, "[the] problem was due not to German inefficiency, but to lack of power in the bi-zonal administrations. To achieve economic recovery, Germans needed a government ... with sufficient power to solve current economic problems." Proposing the Marshall Plan, the United States set up the Bi-zonal Economic Council, a nucleus of the Federal Republic. After the failure of the London Foreign Ministers' Conference in late 1947, Washington took concrete steps toward a separate West German government. A parliamentary council was convened to draft the Basic Law and to form a federal legislature. And soon the

\footnotetext{
${ }^{24}$ Shoemaker (1947) puts the figure of repatriated Koreans after Japanese surrender at about two million. From August 15, 1945 to December 1, 1946 1,099,241 Koreans returned from Japan, 578,555 from Manchuria (including clandestine entries from North Korea via Manchuria), and 390,250 (including refugees) from North Korea.

${ }^{25}$ Lachman (1968) notes that the US government through the Economic Cooperation Administration (ECA) determined what industries European allies should focus on by controlling allocation of aid. Counterpart funds management in particular bestowed the United States an immense say in determining specific programs to be financed.
} 
Federal Constitutional Court and other political institutions were established (Nicholls 1997; Gimbel 1968).

Given that Germany's democratic coalition unraveled due to shrinking outlets abroad in the Great Depression years, the United States strenuously promoted free trade as a countermeasure. Available markets overseas would bolster the reign of export-dependent industries, while checking the resurgence of the protectionist alliance. Germany would then be more likely to stick to liberal internationalism, without falling under authoritarian rule that masterminded the aggressive foreign policy in the 1930s. Expanding export markets would also activate mass production in the country, affording manufacturers greater efficiency and higher profits. German businesses would then become more receptive to the improvement of wages and working conditions. The workers would in turn become more amenable to entreatment for enhancing productivity and refraining from destructive strikes (Hogan 1987).

Rearmament was in line with the plan to rebuild Germany, clinch the nation to the antiSoviet alliance, and tap into its energies for durable peace and prosperity on the continent. US postwar Germany policy was a hotly contested issue by any account: Germany wreaked havoc on its neighbors twice in the past thirty years, and its reconstruction would ineluctably provoke the Soviets. Knowing this, the Germans were half-hearted in such "offensive" endeavors and preferred to remain neutral. With the troop deployment and the Atlantic Treaty, the United States sought to coax the Germans to exert more for rehabilitation, shield them against possible Soviet reprisals, and reintegrate the emerging republic into the West. ${ }^{26}$ Only then could the United States thwart the Kremlin's capacity to mobilize Germany's industrial potential, take control of Western Europe's resources, and jeopardize American interests.

\section{Obstacles to Integration and Preludes to Authoritarianism in Korea}

No sooner had the thirty-five year Japanese colonial rule ended than the liberated Korea was sucked into the maelstrom of revolutionary struggles. Almost ubiquitous People's Committees in particular championed progressive land redistribution and workers' participation in management. The sudden collapse of the brutal dictatorship unleashed passions for extensive reforms, previously stymied by the Japanese colonizer. Military Governor General Hodge (Department of State 1945: 1144-1148) lamented the preponderance of leftist influence: "the US occupation of Korea under present condition and policies is surely drifting to the edge of a political-economic abyss from which it can never be retrieved with any credit to United States prestige in the Far East." $\mathrm{He}$ also confided that southern Korea was an "extremely fertile ground for [the] establishment of Communism" and was on the verge of "an inevitable internal upheaval for its self purification."

Korea possessed relatively little of any great significance. This country was nonetheless crucial for rebuilding Japan and harnessing the archipelago to the anti-Soviet bloc, and the

\footnotetext{
${ }^{26}$ The National Security Council (Truman Papers, PSF, Box 176) agreed in April 1948 that "[another] essential thing in Western Europe, and indeed among all free European countries, is to give confidence. That confidence would have very great repercussions and make the economic steps that have been taken more effective. Therefore the construction of a North Atlantic defence [sic] system would put heart into the whole of Western Europe and would encourage them in their resistance to the infiltration tactics which they have had to face hitherto."
} 


\section{COLD WAR POLICIES IN THE CORE AND THE PERIPHERY 440}

peninsula was thus worth holding onto. ${ }^{27}$ The United States needed to eliminate indigenous leftist groups first, now that their attack on private ownership and control of local political power were incompatible with the goal of creating an "independent, democratic Korea." In uprooting the Left, the Military Government revived the defunct police state. Reinstated Korean police worked side by side with American troops to break up leftist-led protests (Cumings 1981). Because the national police alone could not re-establish order, the occupation authorities decided to set up a constabulary in October 1945. This constabulary gradually absorbed the Korean remnant of the Japanese Army and constituted the national defense forces of the emerging republic (Sawyer 1962).

Alongside its attempts to destroy "hostile elements," the United States nurtured conditions in which a democratic, free market society could survive. The Military Government decreed that the maximum rent should not exceed one-third of the crop, a measure to reduce the burden of desolate tenants and arrest chaos in the country (Mitchell 1949). The Occupation moreover formed a coalition of moderate Left and Right and put it in charge of carrying out land reform. ${ }^{28}$ When the land reform bill ran into deadlock in the conservative-dominated legislature, the Military Government created the National Land Administration. Entrusted with the task of selling ex-Japanese farmlands, the agency fulfilled the job and rectified agrarian inequality to some degree. ${ }^{29}$ This reform attracted farmers to the polls, making the UN-sponsored elections in May 1948 successful and paving the way for the establishment of South Korea in the summer.

Building a pro-American regime in the peninsula, the United States sought to revive South Korea's raw materials production and reconnect its trade ties with Japan. ${ }^{30}$ Despite munificent American aid, the Korean economy continued to stagnate under widespread

\footnotetext{
${ }^{27}$ There existed division in the Truman Administration over Korea policy. It was generally held that South Korea, an asset-poor country, was not important for American military strategy in the Far East (Truman Papers, PSF, Box 176). The Joint Chiefs of Staff thought that the United States "has little strategic interest in maintaining its present troops and bases in Korea." The National Security Council (NSC 8) concurred, stating that "in the event of hostilities in the Far East, these troops would constitute a military liability." The US Central Intelligence Agency (Truman Papers, PSF, Box 177) agreed that Korea was not a good place to fight: "the geographical location of Korea is highly unfavorable for resisting pressures from the north..." The United States hence pulled the combat troops out of South Korea by the summer of 1949. The State Department (Student Research File, Box 1), however, believed that South Korea would be helpful for Japanese economic recovery and that this new republic's successful resistance to communism would shore up American prestige in the region. As a result, although the United States withdrew its combat units, it kept military advisors there and continued to funnel military, economic aid to the South Korean government.

${ }^{28}$ The US Central Intelligence Agency (Truman Papers, PSF, Box 215) reported that "With the distribution of vested lands, a large number of Korean farmers will gain title to land that they formerly cultivated as tenants. The effect on social stratification in Korea cannot be estimated as yet, but it would appear to be of greatest importance to the stability of the government to continue and to expand this program of reform as means of broadening the social base of its popular support, thus counteracting Communist agitation."

${ }^{29}$ Choe (1998) remarks that lands worked by owner-cultivators increased from $35 \%$ to $60 \%$, and tenancy lands shrank from about 3,550,000 acres to $1,840,000$ acres.

${ }^{30}$ The US Central Intelligence Agency (Truman Papers, PSF, Box 215) opined that "Revival of foreign trade between Korea and China and between Korea and Japan... are required for any long-range stabilization of the South Korean economy, even though they may not be politically feasible at the present time."
} 
corruption and rampant inflation. The United States hence pushed the ally to stabilize the currency, specialize in raw materials production, ${ }^{31}$ and resume foreign trade especially with Japan. ${ }^{32}$ Under the aegis of Washington, South Korea signed a trade agreement with Japan in March 1949. The former colony would sell rice, ${ }^{33}$ tungsten, fish products, and fur in exchange for manufactured goods from the neighboring country. Notwithstanding all these endeavors, transplanting liberal democracy in the South was a tantalizing dream, as socio-economic developments theretofore prejudiced interclass compromise. Authoritarianism reigned in South Korea for decades to contain the intractable workers and sympathetic college students (Cumings 1997).

\section{CONCLUSION}

This study shows that neo-pluralism, realism, and world-systems theory have their own merits. Neo-pluralism correctly points out that the business elites significantly influenced America's policy of reintegrating western Germany and southern Korea into the postwar world order. Realism provides a logical explication of the United States' efforts for "balancing" against Soviet threats/power. As Germany appeared to have greater economic, military potential than Korea, America committed itself more to the defense of the former than the latter (Leffler 1992). It decided to rebuild heavy industry in Germany, since doing otherwise could unduly cost postwar European recovery and the anti-Soviet bloc's strategic capabilities (Gaddis 1997). World-systems theory demonstrates robustness in explaining the strength/weakness of the Left in different

\footnotetext{
${ }^{31}$ The United States (Stanley Andrews Papers, Government Service File, Box 3) thought it unwarranted to finance South Korea's production of heavy industrial goods that could be purchased from Japan. "In the [Foreign Aid] memorandum of 24 February [1950] Secretary Voorhees [Under Secretary of the Army Tracey Voorhees] indicated belief that 50 percent of the projected ECA [Economic Cooperation Administration] expenditures for Korea could be used for purchases in Japan, that Japan should shortly be able to supply most of the fertilizer required by Korea, and that construction of a fertilizer plant in Korea seemed both unnecessary and unwise."

${ }^{32}$ A Point IV Program Special Report (Stanley Andrews Papers, Government Service File, Box 3) observed that "In the case of South Korea, a former Japanese possession and now an independent state, it formerly sold its rice and fish to Japan and got industrial, consumer and capital goods back. It has been supported by military and ECA aid in the past four years averaging about 100 million dollars per year - a great part of which went for food, fertilizer, coal and petroleum and very little to capital construction. This was necessary but now production is being restored and the time is coming when Korea will have to look to other than the U.S. Treasury to balance her affairs. The ECA Mission (Korea) estimates that at least 70 percent of the industrial and consumer goods which Korea will need in the future will have to come from Japan and that she will have to pay for these products by shipping rice, fishery products and a few other items to Japan. Japan is the biggest and most assured market for Korean rice in the same manner she is the assured and principal market for Ryukyus and Formosan sugar [underline in original]."

${ }^{33}$ Economic Cooperation Administration (Edgar Johnson Papers, ECA File, Box 1) noted that South Korea's rice export to Japan reached 100,000 metric ton in fiscal year 1950 and the volume would grow almost three-fold in the following year. This agency (John Sumner Papers, ECA File, Box 8) recommended "[increased] agricultural production to provide an export surplus of rice; develop the fisheries industry to add to exportable surpluses" for fiscal year 1950.
} 
countries. The state's economic structure evolves constantly, affecting internal power relations; and these developments often reflect the state's standing in the capitalist world-system.

World-systems theory offers a systematic account for the disparate outcomes of early American cold war policy in different regions. As the United States sought to reinforce the existing international division of labor, its foreign policy toward given countries was generally conditioned by their position in the capitalist world-economy. The United States moved to restore industrial infrastructure in western Germany because this core country was expected to make the most contribution to European recovery with the production of capital goods. America proceeded with rearmament of West Germany to safeguard the ally's collaboration against possible Soviet obstructionism and undercut Moscow's capacity to dominate European resources for its own purposes. The United States, meanwhile, motivated the Korean periphery to specialize in foodstuffs production with a view to assisting Japanese reconstruction. South Korea was also important for anti-Soviet containment: it could act as a buffer that would absorb the ferocity of Soviet influence and help persuade Japan to ally with the free market bloc.

US policy of reintegrating West Germany and South Korea into the international division of labor presupposed that these two countries would remain allied and market-oriented. But divergences in interclass relationships and alliances there created different possibilities for the hegemon to impose its plan. American efforts for economic rehabilitation and democratic reconstruction in Germany did not face serious obstacles. Capital-intensive industrialization there enabled interclass compromise between export-oriented firms and organized labor and rendered its political structure more compatible with democratic development. Lagging behind in capitalist development, Korea lacked a foundation for democracy. Exploitive tenancy farming and factory labor produced disgruntled peasants and workers. These victims of un-tempered capitalism were inborn critics of a free market. Because such inveterate leftists could not be won over, the United States helped defeat them and settled for authoritarian rule.

Beyond the early cold war years, the dynamics of the capitalist world-system became more complex. Postwar economic expansion, coupled with effective neutralization of antidemocratic forces, made politics in West Germany a "harmless game" among moderate centrists (Patton 1999). The United States successfully channeled this young republic's energies into European recuperation and world peace. The American hegemon, however, allowed West Germany to catch up and eventually challenge its economic supremacy. The United States had limited leverage in South Korea as well and came to terms with the ally's pursuance of heavy industrialization. The South should become self-sufficient enough to stand alone without American economic, military aid (Cumings 1997). Washington nevertheless wished South Korea to remain focused on labor-intensive industry, lest this country's production of heavy industrial goods create a glut and generate business losses in the core (Woo 1991). Both West Germany and South Korea managed to resist systemic pressures by exploiting the imperative of nurturing economically viable allies on the East-West "fault-line."

\section{ACKNOWLEDGEMENTS}

The author would like to thank Thomas Conte, Erik Hoffmann, Gregory Nowell, Erol Pedersen, and Benjamin O. Fordham for their helpful comments on the various stages of the manuscript. The author appreciates constructive suggestions by the editors and three anonymous reviewers at 
JWSR. The author also acknowledges the grant from Harry S. Truman Presidential Library that enabled the research at the library.

\section{REFERENCES}

Abraham, David. 1981. The Collapse of the Weimar Republic: Political Economy and Crisis. Princeton: Princeton University Press.

Augelli, Enrico and Craig N. Murphy. 1993. "Gramsci and International Relations: a General Perspective and Example from Recent US Policy toward the Third World." Pages 127147 in Gramsci, Historical Materialism and International Relations, edited by S. Gill. Cambridge: Cambridge University Press.

Block, Fred. 1977. The Origins of International Economic Disorder: A Study of UnitedStates International Monetary Policy from World War II to the Present. Berkeley: University of California Press.

Borden, William. 1985. The Pacific Alliance: United States Foreign Economic Policy and Japanese Trade Recovery, 1947-1955. Madison: University of Wisconsin Press.

Choe, Bok-Cheon. 1998. "Il Bon Gwa Nam Han eseoui Mi Ghoon Jeong Bi Gyo Yon Ghoo [A Comparative Analysis of US Military Occupation in Japan and South Korea]." Master's thesis, Yonsei University, Seoul, Korea.

Cox, Robert. 1996. "Gramsci, Hegemony, and International Relations: An Essay in Method." Pages 124-143 in Approaches to World Order, edited by R. Cox and T. Sinclair. New York: Cambridge University Press.

Cumings, Bruce. 1981. The Origins of the Korean War: Liberation and the Emergence of Separate Regimes 1945-1947. Princeton: Princeton University Press. 1997. Korea's Place in the Sun: A Modern History. New York: W.W. Norton \& Company.

Domhoff, G. William. 1990. The Power Elite and the State: How Policy is Made in America. New York: Aldine De Gruyter.

Eckert, Carter. 1991. Offspring of Empire: The Koch'ang Kims and the Colonial Origins of Korean Capitalism, 1876-1945. Seattle: University of Washington Press.

Eisenberg, Carolyn. 1996. Drawing the Line: the American Decision to Divide Germany, 19441949. New York: Cambridge University Press.

Ferguson, Thomas. 1984. "From Normalcy to New Deal: Industrial Structure, Party Competition, and American Public Policy in the Great Depression." International Organization 38: 41 $-94$.

Fordham, Benjamin. 1998. Building the Cold War Consensus: the Political Economy of U.S. National Security Policy, 1949-51. Ann Arbor: University of Michigan Press.

Gaddis, John Lewis. 1997. We Now Know: Rethinking Cold War History. New York: Oxford University Press. . [1972] 2000. The United States and the Origins of the Cold War, 1941-1947. New York: Columbia University Press.

Gibbs, David. 1990. The Political Economy of Third World Intervention. Chicago: The University of Chicago Press. 
Gimbel, John. 1968. The American Occupation of Germany: Politics and the Military, $1945-$ 1949. Stanford: Stanford University Press.

Harry S. Truman Library. 1977. "Oral History Interview with Charles P. Kindleberger." Independence, MO: Harry S. Truman Library. Retrieved June 2, 2006. (http://www.trumanlibrary.org/oralhist/kindbrgr.htm). . 1990. "Oral History Interview with Paul H. Nitze." Independence, MO: Harry S. $\begin{array}{llll}\text { Truman Library. } & \text { Retrieved } & \end{array}$ (http://www.trumanlibrary.org/oralhist/nitzeph1.htm).

Harry S. Truman Library Student Research File. Harry S. Truman Library. Independence, MO.

Hogan, Michael. 1987. The Marshall Plan: America, Britain, and the Reconstruction of Western Europe, 1947-1952. New York: Cambridge University Press.

Kahin, Audrey R. and George McT. Kahin. 1995. Subversion as Foreign Policy: The Secret Eisenhower and Dulles Debacle in Indonesia. Seattle: University of Washington Press.

Kindleberger, Charles P. 1987. Marshall Plan Days. Boston: Allen \& Unwin.

Kofski, Frank. n.d. "Did the Truman Administration Deliberately Prolong the Korean War?" Unpublished Manuscript.

Kolko, Joyce and Gabriel Kolko. 1972. The Limits of Power: The World and United States Foreign Policy, 1945-1954. New York: Harper \& Row.

Lachman, Alexis. 1968. The Local Currency Proceeds of Foreign Aid. Paris: Development Centre of the Organization for Economic Cooperation and Development.

Leffler, Melvyn. 1992. A Preponderance of Power: National Security, the Truman Administration, and the Cold War. Stanford: Stanford University Press.

Lewis, Cleona. 1941. Nazi Europe and World Trade. Washington DC: The Brookings Institution.

Lundestad, Gerr. 1984. "Empire by Invitation? The United States and Western Europe, 19451952." SHAFR News Letter 15: 1 - 21.

Machlup, Fritz. 1977. A History of Thought on Economic Integration. New York: Columbia University Press.

Maier, Charles. S. 1977. "The Politics of Productivity: Foundations of American International Economic Policy after World War II.” International Organization 31: 607 - 633.

Mayer, Herbert. 1969. German Recovery and the Marshall Plan, 1948-1952. New York: Atlantic Forum.

McCormick, Thomas. 1989. America's Half-Century: United States Foreign Policy in the Cold War. Baltimore: The Johns Hopkins University Press.

Meade, E. Grant. 1951. American Military Government in Korea. New York: King's C Crown Press, Columbia University.

Migdal, Joel. 1974. Peasants, Politics, and Revolution: Pressures toward Political and Social Change in the Third World. Princeton: Princeton University Press.

Mitchell, Charles Clyde, Jr. 1949. "The New Korea Company, Limited: Land Management and Tenancy Reform in Korea against a Background of United States Army Occupation, 1945-1948." Ph.D. dissertation, Harvard University, Cambridge, MA.

Moeller, Robert. 1986. German Peasants and Agrarian Politics, 1914-1924: The Rhineland and Westphalia. Chapel Hill: The University of North Carolina Press.

Moon, Katharine H. S. 1997. Sex among Allies: Military Prostitution in U.S. - Korea Relations. New York: Columbia University Press. 
Nicholls, Anthony. 1997. The Bonn Republic: West German Democracy 1945-1990. Addison Wesley Longman Inc.

Paige, Jeffrey. 1975. Agrarian Revolution: Social Movements and Export Agriculture in the Underdeveloped World. New York: The Free Press.

Papers of Stanley Andrews. Government Service File. Harry S. Truman Library. Independence, MO.

Papers of Edgar Johnson. ECA File. Harry S. Truman Library. Independence, MO.

Papers of Leon Keyserling. Council of Economic Advisors File. Harry S. Truman Library. Independence, MO.

Papers Walter Salant. Point IV Files. Harry S. Truman Library. Independence, MO.

Papers of John Sumner. ECA File. Harry S. Truman Library. Independence, MO.

Papers of President Harry S. Truman. President's Secretary's Files. Harry S. Truman ～Library. Independence, MO.

Patton, David. 1999. Cold War Politics in Postwar Germany. New York: St. Martin's Press.

Plake, F. Marvin. 1951. "A Practical Program." Pages 34-38 in The Point Four Program, edited by W. Daniels. New York: The H.W. Wilson Company.

Policy Planning Staff. 1983. The State Department Policy Planning Staff Papers 1948, Volume II. New York: Garland Publishing, Inc.

Sawyer, Robert. 1962. Military Advisors in Korea: KMAG in Peace and War. Washington DC: Office of the Chief of Military History, Department of the Army.

Shannon, Thomas. R. 1989. An Introduction to the World-System Perspective. Boulder: Westview Press.

Shoemaker, James. 1947. Notes on Korea's Postwar Economic Condition. New York: Institute of Pacific Relations.

Shoup, Laurence and William Minter. 1977 Imperial Brain Trust: the Council on Foreign Relations and United States Foreign Policy. New York: Monthly Review Press.

Silver, Beverly J. and Eric Slater. 1999. "The Social Origins of World Hegemonies." Pages 151216 in Chaos and Governance in the Modern World System, edited by G. Arrighi and B. Silver. Minneapolis: University of Minnesota Press.

US Department of Commerce. 1968. Foreign Commerce Yearbook 1936 and 1938. New York: Greenwood Press, Publishers.

US Department of State. 1945. Foreign Relations of the United States. VI. Washington: Government Printing Office. . 1948. Foreign Relations of the United States. VI. Washington: Government Printing Office.

Wallerstein, Immanuel. 1979. The Capitalist World-Economy. New York: Cambridge University Press.

. 1984. The Politics of the World-Economy: the States, the Movements, and the Civilizations. New York: Cambridge University Press.

Walt, Stephan. 1987. The Origins of Alliances. Ithaca: Cornell University Press.

Waltz, Kenneth. 1979. Theory of International Politics. Reading: Addison-Wesley Publishing Company.

Woo, Jung-en. 1991. Race to the Swift: State and Finance in Korean Industrialization. New York: Columbia University Press. 